\title{
The Harstad injury prevention study: the epidemiology of sports injuries. An 8 year study
}

\author{
Børge Ytterstad
}

\begin{abstract}
Objective-To describe the epidemiology of sports injuries occurring in a community during 8 years and to evaluate the outcome of an intervention implemented against injuries occurring in downhill skiing.

Methods-Hospital treated sports injuries occurring in Harstad, Norway (population 22 600) were recorded prospectively during an 8 year period. A prevention programme targeting downhill skiing injuries was evaluated.

Results-2234 sports injuries accounted for $17 \cdot 2 \%$ of recorded unintentional injuries. Two out of three injuries occurred in team sports. Soccer accounted for $44.8 \%$ of all sports injuries. Downhill skiing injuries had higher mean score on the abbreviated injury scale than all other sports analysed combined $(P<0 \cdot 01)$. Postintervention injury rates for downhill skiing were reduced by $15 \%$ when adjusting for exposure $(P=0 \cdot 24)$. Further observations are needed for assessing the effectiveness of the downhill skiing safety programme.

Conclusions-Strategies for future sports injury prevention include community involvement, particularly sports organisations. Local data analysis seems to justify some priorities, for example, promotion of helmet use in downhill skiing for young adolescents and prevention of lower limb fractures in male soccer players $15+$ years old. Prospective hospital recording of injuries provides a tool for the design and outcome evaluation of sports injury intervention research.

(BrF Sports Med 1996;30:64-68)
\end{abstract}

Key terms: soccer; downhill skiing; sports; injury; prevention

Sports injuries are an important cause of morbidity in Norway, with incidence ranking next to injuries in the home. ${ }^{1}$ Because of the high incidence, sports injuries needing hospital treatment require considerable outpatient and inpatient resources. ${ }^{2}{ }^{3}$ The World Health Organisation has emphasised the importance of injury control (Health for All Year 2000). The goal for Europe is to reduce injury, disability, and death from accidents, including sports accidents, by at least $25 \%{ }^{4}$ High quality epidemiological data are essential for the planning, development, and evaluation of efforts to prevent injuries. ${ }^{5}$ For local sports injury prophylaxis the use of national aggregate data is of limited value because different populations seem to have special epidemiological characteristics $^{267}$ and the use of local data is advantageous for selecting targets for injury prophylaxis. $^{8}$

Different approaches for preventing sports injuries have been recommended: for example, promotion of protective equipment use, ${ }^{9}$ adequate warming up before competition, ${ }^{10}$ or the implementation of a routine prophylaxis programme before training or games. ${ }^{11}$ The latter was found to be effective for prevention of soccer injuries. ${ }^{11}$ In a community based injury prevention study in Sweden a significant decrease in overall injury rates was reported, but the study did not specifically target sports injuries. ${ }^{8}$ Although a few studies have described prospective and complete recording of sports injuries in a defined population, ${ }^{23}$ ours is the first prospective study of such long duration (eight years), including a preventive part.

The aims of this study were to describe the epidemiology of sports injuries occurring in a community during eight years and to evaluate the outcome of an intervention implemented against injuries occurring in downhill skiing.

\section{Methods}

STUDY DESIGN

The present paper describes the sports injury component of the comprehensive Harstad injury prevention study. ${ }^{12-14}$ The city of Harstad has a population of 22600 and is located $250 \mathrm{~km}$ north of the Arctic circle. The study lasted for eight years. The intervention component (downhill skiing) had a baseline of five years and an intervention period of three years.

\section{DEFINITION}

A sports injury was defined in this study as an unintentional injury occurring during games or physical training in an area specially designed for sports activities, for example soccer stadiums, gymnasiums, downhill skiing slopes, ski jumping installations, and skating rinks. Injuries occurring during horseback riding or during non-competitive physical exercise in the open air and recreational areas are excluded.

\section{DATA RECORDING}

The prospective data recording started 1 July 1985 and lasted for eight years. During this time data on all injured persons treated in the hospital emergency ward were recorded, and included in an injury database. The variables for each case were selected in cooperation with The National Institute of Public Health ${ }^{1}$ as part of a national injury surveillance system and followed the Nordic coding system. ${ }^{15}$ 
VARIABLES IN THE INJURY DATABASE

Demographic data collected were age, gender, and place of residence. Activity type, place of injury, type of sport, product involved, and date and time of injury were recorded. An open ended question (free text) described the event leading to the injury. This free text contained three distinct parts that are partly consistent with the concepts of precrash, crash, and postcrash described by Haddon. ${ }^{16}$ Medical variables were injury type, injury mechanism, body part injured, and admittance to the hospital. Injury severity was coded according to the abbreviated injury scale (AIS). ${ }^{17}$

DATA RECORDING PROCEDURE, ANALYSIS, VALIDITY, AND RELIABILITY

The recorded variables, data recording procedure, and measures taken to ensure data validity and reliability of the injury database are described in more detail elsewhere. ${ }^{12-14}$

To aid prophylaxis planning, a separate analysis was completed for children (0-14 years) and adolescents/adults (15+ years).

DOWNHILL SKIING INIURY PREVENTION

Harstad municipality has one ski resort (opened in 1985) with ski lift and slopes for downhill skiing, run by the Harstad Alpine Club. Practically all hospital treated downhill skiing injuries come from this installation. Data from injured skiers recorded during the first years of the present study were analysed and discussed in the Harstad community injury prevention group (IPG). The function and composition of this group is described elsewhere. ${ }^{12-14}$ The data with free texts (victim stories) were sent to the Harstad Alpine Club, together with some recommendations for targeting interventions: (1) promotion of increased helmet use and properly fitted boots and bindings; (2) prevention of injuries occurring from collisions with trees and rocks while skiing outside the downhill area; (3) prevention of injuries resulting from high speed skiers within the area running into objects or other skiers; and (4) prevention of injuries connected with the ski lift.

\section{STATISTICS}

Because of warmer winters in the intervention period, injury rates for downhill skiing were adjusted for exposure. For the other sports, the incidence rates given were not analysed with regard to duration of exposure to the sporting

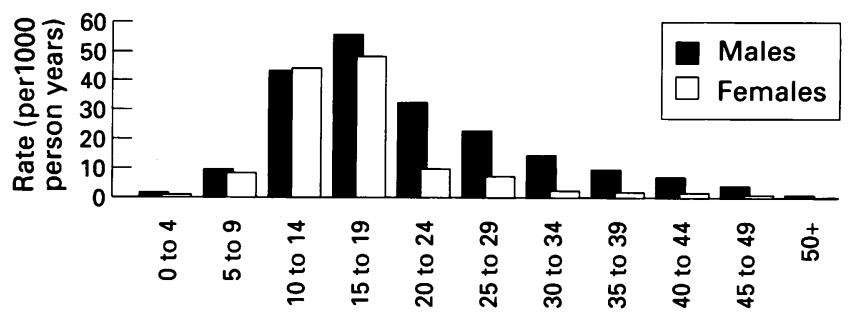

Age groups

The Harstad injury prevention study: age and sex specific sports injury rates $(n=2234)$ recorded during eight years, starting 1 fuly 1985. activity, but were based on population census data. Epi info version 5.01 package was used for analysis. ${ }^{18}$ The $\chi^{2}$ test was used for testing injury rate changes and incidence rate differences. ${ }^{19}$ The Kruska-Wallis test was used for comparing means. $\mathrm{P}$ values below 0.05 were regarded as significant.

\section{Results}

INJURY RATE VARIATIONS DURING THE STUDY Of 12977 unintentional injuries recorded in Harstad residents from 1 July 1985 to 30 June $1993,2234(17 \cdot 2 \%)$ were sports injuries, yielding a mean sports injury rate of 12.5 per 1000 person-years. During the study the yearly overall crude sport injury rate was stable (table 1).

AGE AND SEX DISTRIBUTION FOR INJURY MECHANISM, INJURY TYPE, AND BODY PART INJURED

Of the injured, $63.4 \%$ were males who, compared with females, had a higher mean injury rate $(16.0 v 9 \cdot 1$ per 1000 person-years, $\mathrm{P}<0.01)$ and were older $(21.8 v 17.2$ years, $P<0.01) ; 80.5 \%$ of injuries occurred in people between 10 and 30 years of age (figure).

\section{Injury mechanism}

Falls and trauma from contact with persons or objects accounted for three out of four injuries. The sex distribution of injury mechanisms for two different age groups is shown in table 2 .

\section{Injury type}

Of those injured, $49.6 \%$ had sprains (partial or total ligament ruptures) or dislocations, $23 \cdot 3 \%$ had open wounds, excoriations, or contusions, $18.4 \%$ had fractures, and $2.6 \%$ had concussions or more serious brain injury. Internal injury (other than intracranial) was observed in $0.8 \%$, and $5.5 \%$ had multiple injuries, other injury types, or no information. The injury type variations by sex and different age groups are shown in table 3 .

\section{Body part injured}

As a mean of overall recoded injuries, lower extremities were injured in $54.1 \%$, upper extremities in $29.5 \%$, the head in $10.0 \%$, and other or multiple body parts in $5.9 \%$ of cases. In children, boys suffered injuries of the head, thorax, abdomen, and spine more often than girls (data not shown). Data about body part injured were missing in $0.4 \%$ of cases.

Table 1 Sports injury rates in Harstad residents by study year. From 1 Fuly 1985

\begin{tabular}{llcl}
\hline $\begin{array}{l}\text { Study } \\
\text { year }\end{array}$ & $n$ & $\begin{array}{l}\text { Per cent of } \\
\text { study total }\end{array}$ & $\begin{array}{l}\text { Rate } \\
\text { (per 1000 person-years) }\end{array}$ \\
\hline 1 & 266 & $11 \cdot 9$ & $12 \cdot 1$ \\
2 & 280 & $12 \cdot 5$ & $12 \cdot 7$ \\
3 & 282 & $12 \cdot 6$ & $12 \cdot 7$ \\
4 & 289 & $12 \cdot 9$ & $12 \cdot 9$ \\
5 & 284 & $12 \cdot 7$ & $12 \cdot 7$ \\
6 & 282 & $12 \cdot 6$ & $12 \cdot 6$ \\
7 & 272 & $12 \cdot 2$ & $12 \cdot 0$ \\
8 & 279 & $12 \cdot 5$ & $12 \cdot 3$ \\
Total & 2234 & $100 \cdot 0$ & $12 \cdot 5$ \\
\hline
\end{tabular}


Table 2 All sports: per cent distribution of injury mechanism by sex and age groups

\begin{tabular}{|c|c|c|c|c|c|c|c|c|c|c|}
\hline \multirow{3}{*}{$\begin{array}{l}\text { Injury } \\
\text { mechanism }\end{array}$} & \multicolumn{5}{|c|}{$0-14$ years } & \multicolumn{5}{|c|}{$15+$ years } \\
\hline & \multicolumn{2}{|c|}{ Males } & \multicolumn{2}{|c|}{ Females } & \multirow[b]{2}{*}{$P$} & \multicolumn{2}{|l|}{ Males } & \multicolumn{2}{|c|}{ Females } & \multirow[b]{2}{*}{$P$} \\
\hline & $n$ & $\%$ & $n$ & $\%$ & & $n$ & $\%$ & $n$ & $\%$ & \\
\hline $\begin{array}{l}\text { Falls } \\
\text { Contact trauma } \\
\text { Acute strain } \\
\text { Othert } \\
\text { No information }\end{array}$ & $\begin{array}{r}152 \\
137 \\
31 \\
6 \\
2\end{array}$ & $\begin{array}{r}46 \cdot 3 \\
41 \cdot 8 \\
9 \cdot 5 \\
1 \cdot 8 \\
0 \cdot 6\end{array}$ & $\begin{array}{r}143 \\
127 \\
37 \\
3 \\
4\end{array}$ & $\begin{array}{r}45 \cdot 5 \\
40 \cdot 4 \\
11 \cdot 8 \\
1 \cdot 0 \\
1 \cdot 3\end{array}$ & $0.815 \ddagger$ & $\begin{array}{r}289 \\
484 \\
282 \\
15 \\
18\end{array}$ & $\begin{array}{r}26 \cdot 6 \\
44 \cdot 5 \\
25 \cdot 9 \\
1 \cdot 4 \\
1 \cdot 7\end{array}$ & $\begin{array}{r}182 \\
173 \\
139 \\
7 \\
3\end{array}$ & $\begin{array}{r}36 \cdot 1 \\
34 \cdot 3 \\
27 \cdot 6 \\
1 \cdot 4 \\
0 \cdot 6\end{array}$ & $0.0001 \ddagger$ \\
\hline Total & 328 & $100 \cdot 0$ & 314 & $100 \cdot 0$ & - & 1088 & $100 \cdot 1$ & 504 & $100 \cdot 0$ & - \\
\hline
\end{tabular}

*Trauma sustained from contact with person or object.

†Includes cuts, foreign body and thermal/chemical injury.

$\neq$ For a $2 \times 4$ table (other and no information analysed combined). Three degrees of freedom.

Table 3 All sports: per cent distribution of injury type by sex and two different age groups

\begin{tabular}{|c|c|c|c|c|c|c|c|c|c|c|}
\hline \multirow[t]{3}{*}{ Injury type } & \multicolumn{5}{|c|}{$0-14$ years } & \multicolumn{5}{|c|}{$15+$ years } \\
\hline & \multicolumn{2}{|c|}{ Males } & \multicolumn{2}{|c|}{ Females } & \multirow[b]{2}{*}{$P$} & \multicolumn{2}{|l|}{ Males } & \multicolumn{2}{|c|}{ Females } & \multirow[b]{2}{*}{$P$} \\
\hline & $n$ & $\%$ & $n$ & $\%$ & & $n$ & $\%$ & $n$ & $\%$ & \\
\hline $\begin{array}{l}\text { Sprains or dislocation } \\
\text { Fractures } \\
\text { Concussion* } \\
\text { Internal injuryt } \\
\text { Wounds, contusions } \\
\text { Multiple, other, no inform. }\end{array}$ & $\begin{array}{r}108 \\
87 \\
16 \\
1 \\
100 \\
16\end{array}$ & $\begin{array}{r}32 \cdot 9 \\
26 \cdot 5 \\
4 \cdot 9 \\
0 \cdot 3 \\
30 \cdot 5 \\
4 \cdot 9\end{array}$ & $\begin{array}{r}146 \\
60 \\
11 \\
2 \\
83 \\
12\end{array}$ & $\begin{array}{r}46 \cdot 5 \\
19 \cdot 1 \\
3 \cdot 5 \\
0 \cdot 6 \\
26 \cdot 4 \\
3 \cdot 8\end{array}$ & $0.01 \ddagger$ & $\begin{array}{r}547 \\
198 \\
17 \\
12 \\
242 \\
72\end{array}$ & $\begin{array}{r}50 \cdot 3 \\
18 \cdot 2 \\
1 \cdot 6 \\
1 \cdot 1 \\
22 \cdot 2 \\
6 \cdot 6\end{array}$ & $\begin{array}{r}306 \\
66 \\
13 \\
2 \\
95 \\
22\end{array}$ & $\begin{array}{r}60 \cdot 7 \\
13 \cdot 1 \\
2 \cdot 6 \\
0 \cdot 4 \\
18 \cdot 2 \\
4 \cdot 4\end{array}$ & $0.0004 \ddagger$ \\
\hline Total & 328 & $100 \cdot 0$ & 314 & $100 \cdot 0$ & - & 1088 & $100 \cdot 0$ & 504 & $100 \cdot 0$ & - \\
\hline
\end{tabular}

^Or more serious brain injury.

†Except intracranial.

¥For a $2 \times 5$ table (internal injury and multiple, other, no inform. analysed combined). Four degrees of freedom.

INJURY DISTRIBUTION AND CHARACTERISTICS WITHIN SPORTS

Sex variation

Soccer accounted for most injuries, followed by downhill skiing. Males injured while playing soccer represented $36.8 \%$ of the population injured, and $9 \cdot 1 \%$ were female handball players (table 4).

Injury type and seriousness according to abbreviated injury scale

One hundred and eighty nine fractures and 499 sprains in soccer accounted for $30.1 \%$ of all

Table 4 Distribution of injuries by sport and sex

\begin{tabular}{lrllr}
\hline Sport & $n$ & Males $\%$ & $P \dagger$ & \% of total \\
\hline Soccer & 1001 & $82 \cdot 3$ & $0 \cdot 00$ & $44 \cdot 8$ \\
Handball & 246 & $17 \cdot 5$ & $0 \cdot 00$ & $11 \cdot 0$ \\
Volleyball & 155 & $43 \cdot 2$ & NS & $6 \cdot 9$ \\
Basketball & 95 & $44 \cdot 2$ & NS & $4 \cdot 3$ \\
Downhill & 251 & $64 \cdot 1$ & $0 \cdot 00$ & $11 \cdot 2$ \\
OtherS & 435 & $56 \cdot 6$ & NS & $19 \cdot 5$ \\
Missing data & 51 & $64 \cdot 7$ & NS & $2 \cdot 3$ \\
Total & 2234 & - & - & $100 \cdot 0$ \\
\hline
\end{tabular}

*Female percentage may be calculated.

†For testing sex difference within sport.

SIncludes tennis, squash, land hockey, ice hockey, ski jumping,

cross country skiing, scating, body building, judo, jiu-jitsu,

karate, boxing, gymnastics, track and swimming.

Table 5 Distribution of injury type in percent and injury seriousness according to abbreviated injury scale (AIS) within sports

\begin{tabular}{|c|c|c|c|c|c|c|c|c|}
\hline Sport & $\begin{array}{l}\text { Fractures } \\
(\%)\end{array}$ & $\begin{array}{l}\text { Ligament } \\
\text { ruptures } \\
\text { (sprains) } \\
(\%)\end{array}$ & $\begin{array}{l}\text { Concussion or } \\
\text { more serious } \\
\text { brain injury } \\
(\%)\end{array}$ & $\begin{array}{l}\text { Other internal or } \\
\text { multiple lesions } \\
(\%)\end{array}$ & $\begin{array}{l}\text { Wounds and } \\
\text { contusions } \\
(\%)\end{array}$ & $\begin{array}{l}\text { Other or } \\
\text { unknown injury } \\
(\%)\end{array}$ & $\begin{array}{l}\text { Mean score } \\
(A I S)\end{array}$ & $\begin{array}{l}\text { Total } \\
(n)\end{array}$ \\
\hline $\begin{array}{l}\text { Soccer } \\
\text { Handball } \\
\text { Volleyball } \\
\text { Basketball } \\
\text { Downhill } \\
\text { Other` } \\
\text { Missing }\end{array}$ & $\begin{array}{r}18 \cdot 9 \\
12 \cdot 6 \\
9 \cdot 0 \\
16 \cdot 8 \\
23 \cdot 9 \\
21 \cdot 1 \\
17 \cdot 6\end{array}$ & $\begin{array}{l}49 \cdot 9 \\
59 \cdot 8 \\
70 \cdot 3 \\
67 \cdot 4 \\
36 \cdot 3 \\
40 \cdot 0 \\
45 \cdot 1\end{array}$ & $\begin{array}{l}1 \cdot 8 \\
3 \cdot 3 \\
0 \cdot 0 \\
0 \cdot 0 \\
5 \cdot 6 \\
3 \cdot 7 \\
2 \cdot 0\end{array}$ & $\begin{array}{l}0 \cdot 8 \\
0 \cdot 8 \\
1 \cdot 3 \\
0 \cdot 0 \\
2 \cdot 4 \\
1 \cdot 0 \\
5 \cdot 9\end{array}$ & $\begin{array}{l}23 \cdot 7 \\
18 \cdot 7 \\
13 \cdot 5 \\
11 \cdot 6 \\
27 \cdot 1 \\
29 \cdot 0 \\
21 \cdot 6\end{array}$ & $\begin{array}{l}5 \cdot 0 \\
4 \cdot 9 \\
5 \cdot 8 \\
4 \cdot 3 \\
4 \cdot 8 \\
5 \cdot 2 \\
7 \cdot 8\end{array}$ & $\begin{array}{l}1.175 \\
1.126 \\
1.116 \\
1.095 \\
1.363 \\
1.175 \\
1.235\end{array}$ & $\begin{array}{r}1001 \\
246 \\
155 \\
95 \\
251 \\
435 \\
51\end{array}$ \\
\hline Total N & 411 & 1107 & 57 & 25 & 520 & 114 & - & 2234 \\
\hline
\end{tabular}

${ }^{\star}$ Includes tennis, squash, land hockey, ice hockey, ski jumping, cross country skiing, scating, body building, judo, kiu-jitsu, karate, boxing, gymnastics, track and swimming.

AIS, abbreviated injury scale. injuries. Fractures and concussions were the most frequent types of injury in downhill skiing. All but one injury (a downhill skiing injury with AIS 5) had AIS < 4. The mean AIS score was higher in downhill skiing than in all other variability was observed between the other sports (table 5 ).

\section{ADMITTED CASES}

The variable "admitted to hospital" was recorded for the seven last years of the study, during which $5 \cdot 6 \%$ of the recorded sport injuries led to admittance $(n=112)$. Soccer accounted for $30.4 \%$ and downhill skiing for $28.6 \%$ of admittances, while $41 \%$ of admitted cases occurred in all other sports combined. Females were admitted in $3.3 \%$ of recorded cases and males in $7 \cdot 0 \%$. Mean age was 24.5 years for males and 21.9 for females. Of the admitted cases, $29 \cdot 5 \%$ had fractures, $26 \cdot 8 \%$ had ligament ruptures, wounds, contusions, or dislocations, $25.0 \%$ had concussions or more serious neurological deficit, $1 \cdot 8 \%$ had internal injury other than intracranial, $3.6 \%$ had multiple injuries, and $13.4 \%$ had other injury types. sports analysed combined $(P<0.01)$. Little 
Table 6 Injury count and rates per 10000 person-years (in parentheses) for different sports by study period.

Period 1 (5 years) = baseline; period 2 (3 years) included interventions for downhill skiing

\begin{tabular}{lccccccc}
\hline & Soccer & Handball & Volleyball & Basketball & Downhill & Other & Missing \\
\hline Period 1 & $617(55 \cdot 6)$ & $146(13 \cdot 2)$ & $100(9 \cdot 0)$ & $64(5 \cdot 8)$ & $179(16 \cdot 1)$ & $263(23 \cdot 7)$ & $32(2 \cdot 9)$ \\
Period 2 & $384(56 \cdot 8)$ & $100(14 \cdot 8)$ & $55(8 \cdot 1)$ & $31(4 \cdot 6)$ & $72(10 \cdot 6)$ & $172(25 \cdot 4)$ & $19(2 \cdot 8)$ \\
Relative risk for period 2 & $1 \cdot 02$ & $1 \cdot 12$ & 0.90 & $0 \cdot 80$ & $0 \cdot 85^{\star}$ & $1 \cdot 07$ & $0 \cdot 97$ \\
P value & $0 \cdot 767$ & 0.402 & 0.599 & $0 \cdot 345$ & $0 \cdot 24^{\star}$ & 0.500 & 0.955 \\
\hline
\end{tabular}

^Adjusted for exposure.

INTERVENTION: INJURY RATES FOR DOWNHILI SKIING COMPARED TO OTHER SPORTS

A $15 \%$ decrease in downhill skiing injury rates was observed between the five year baseline period and the three year intervention period (adjusted for exposure, $P=0 \cdot 24$ ). Concomitantly the injury rates were more or less stable in the other sports (table 6). The admittance rate for downhill skiing injuries was reduced from $2 \cdot 8$ per 10000 person years (the last four years of baseline) to 1.0 per 10000 person years (intervention period) (data not shown).

\section{Discussion}

THE LOCAL EPIDEMIOLOGY OF SPORTS INJURY

Some of the epidemiological characteristics in our study are similar to other Scandinavian studies describing prospective injury recording: for example, the proportion of sports injuries relative to all injuries, mean age, female to male ratio, and the dominant position of soccer in the injury panorama. ${ }^{36}$ There are, however, some differences in the proportion of different sports injuries, mostly accounted for by geography and local cultural differences. Downhill skiing injuries had the highest frequency of fractures and concussions. This is consistent with a significantly higher AIS score in this sport. Nevertheless, while injuries sustained in downhill skiing were a major problem in our study, they are much less so in the studies from the flat parts of Sweden. ${ }^{36}$ Ice hockey, however, which accounted for a major part of sport injuries in these Swedish studies, is uncommon in Harstad.

\section{TRENDS FOR SPORT INJURY RATES}

The stability of overall sports injury rates observed during an eight year period may be interpreted as an indication of a reliable and stable hospital injury recording system. This assessment could be biased by (1) an increasing risk exposure due to a population increasingly participating in sports activities, and (2) a registration loss at the end of the study (registration effect). However, to our knowledge, participation in sports related activities has not been on the rise in Harstad. The possibility of a registration effect has been assessed earlier, ${ }^{12-14}$ and was found to be an unlikely occurrence. Information for assessing exposure was only available for downhill skiing. Data from the Harstad Alpine Club (personal communication) indicated a lower exposure during the last three years of the study (intervention period) compared to the first five years (baseline). Due to weather conditions, the ski resort had fewer days open per year during the last three years (intervention period) compared to baseline. The relative risk of getting a downhill skiing injury between the baseline non-intervention period and the intervention period, when adjusted for the above mentioned exposure difference, was 0.85 (confidence intervals $0.66,1 \cdot 10)(P=0.24)$. These figures must be interpreted with caution. Future injury rate calculations based on continuous prospective recordings may help to indicate whether the ongoing downhill safety programme is effective or the calculated $15 \%$ injury rate reduction is due to random variations in accidents.

\section{PREVENTION STRATEGIES}

General strategic planning should take into consideration the major epidemiological findings in this study, for example, age and sex distribution, main injury mechanisms, injury type, and body part injured.

\section{School involvement}

Given that sports injuries occur most often during the second decade of life (figure), it seems reasonable to involve schools more in prophylaxis, for example, information to individuals, parents, and coaches. The latter are often recruited from parents or teachers.

\section{Protective equipment}

Nearly half of the injured children were injured in falls. This could indicate a need for more sturdy footwear for children engaged in sports. Male children suffered head injuries and concussion most frequently (table 3 ). Out of 31 head injuries observed in downhill skiing, 17 (55\%) occurred in 11-15 year olds (data not shown). This could indicate resistance in Harstad to helmet use in this age group. Such resistance has been reported by others. ${ }^{9}$ A Swedish study of injuries in downhill skiing reported a distinct decline in helmet use from $66 \%$ in $9-11$ years old children to $21 \%$ in 12-14 year olds. ${ }^{9}$ Strategies for achieving increased helmet use in this age group must be given priority. Mandatory helmet use should be considered.

\section{Team sports}

Team sports accounted for two out of three injuries, soccer injuries being the most frequent (table 4). Obviously the prevention of team sport injuries in general and soccer injuries in particular must be given high priority. Ekstrand et al have shown that a prevention programme can reduce soccer injuries by as much as $75 \%$ (including overuse injuries). ${ }^{11}$ The programme is made up of seven different parts and can be used in most team sports: correction of training, protection by correct equipment, prophylactic ankle taping, controlled rehabilitation after injury, exclusion of 
players with knee instability, information to coaches and players, correction and supervision by doctors and physiotherapists.

Out of 1001 soccer injuries in our study, $63.8 \%$ occurred in the lower extremities (data not shown). Fractures are costly to patients and the health services in terms of suffering, debility, and expenditure of hospital resources. Accordingly this injury type should be a high priority target in planning prophylaxis. Fractures of the lower extremities occurring during tackles in soccer can be prevented by the use of proper protective equipment (shin guards). ${ }^{11}$ Our data showed that males $15+$ years old suffered 53 out of 71 fractures of lower extremities occurring in soccer, identifying them as an important subgroup for intervention. Strategic considerations for prophylaxis should include checks on compliance with mandated use of shin guards and adequate referee reaction to rule violations.

According to the principle adapted by the Harstad injury prevention programme, effective prophylaxis may be initiated by the injury prevention group (IPG) and planned/ implemented in cooperation with relevant organisations, ${ }^{12-14} 20$ for example, the local branches of the Norwegian associations for the team sports (soccer, handball, volleyball, basketball), municipal authorities, and the health services.

\section{Individual sports}

The most important individual sport in our study is downhill skiing. A renewed effort for further cooperation with the Harstad Alpine Club is needed in promoting the observation of safety regulations, use of correct bindings and protective equipment, and supervised and directed skill training. This model for prophylactic work can be used in most individual sports.

\section{CONCLUSIONS}

(1) Continuous prospective hospital recording of sports injuries in a community is feasible and provides a tool for evaluating the outcome of sports injury prevention programmes. (2) Local sports injury prophylaxis may be improved by using local epidemiological knowledge in community based interventions. (3) Although a postintervention $15 \%$ reduction was observed in downhill skiing injury rates (adjusted for exposure), the present study has not presented conclusive evidence of an effective intervention against downhill skiing injuries in Harstad. A basis is provided for designing an injury prevention programme covering most sports.

This study has been supported by The Norwegian Research Council for Science and the Humanities (NAVF).

1 Guldvog B, Thorgersen A, Ueland Ø. Rapport $n r$ 1/92 Ulykker, vold og selvpafort skade. Personskaderapport. [Accidents, violence and self-inflicted injury] Oslo: National [Accidents, violence and self-inflicted injury] Oslo: N

2 Sahlin Y. Injury registration. A tool for accident preventive work. Trondheim, Norway: Tapir, 1990 [thesis].

3 Lindqvist K. Towards community-based injury prevention. The Motala model. Linkøping, Sweden: Linkøping University, 1993 [thesis]

4 World Health Organisation. Regional targets in support of the regional strategy for health for all. EUR/RC34/7. Regional Office for Europe, 34th session. Copenhagen: WHO September 24-9, 1984.

5 Committee on Trauma Research. Injury in America. A continuing public health problem. Washington DC: National Academy Press, 1985.

6 de Loës $M$, Goldie I. Incidence rate of injuries during sport activity and physical exercise in a rural Swedish municipality: incidence rates in 17 sports. Int $\mathcal{F}$ Sports Med 1989;9:461-7.

7 Lorentzon R, Johansson C, Bjørnstig U. Fotbollen orsakar flest skador men badmintonskadan er dyrast. orsakar flest skador men badmintonskadan
Läkartidningen 1984;81:340-3. (In Swedish.)

8 Schelp L. Community intervention and changes in accident pattern in a rural Swedish municipality. Health Promotion pattern in a rural

9 Jansson C, Bauer M. Utförsåkning den största enskilda orsaken til skador vid vintersport bland barn. Läkartidningen 1991;88:1586-9. (In Swedish.)

10 Shephard RJ. Limitations upon the rate of working. In Shephard RJ, ed. Physiology and biochemistry of exercise. New York: Praeger Publ, 1982:90-2.

11 Ekstrand J, Gillquist J, Liljedahl SO. Prevention of soccer injuries. Supervision by doctor and physiotherapists. $A m$ f Sports Med 1983;11:116-20.

12 Ytterstad B, Wasmuth $\mathrm{HH}$. The Harstad injury prevention study: evaluation of hospital-based injury-recording and community-based intervention for traffic injury prevention. Accid Anal Prev 1995;27:111-23.

13 Ytterstad B, Søgaard AJ. The Harstad injury prevention study: prevention of burns in small children by vention study: prevention of burns in small children by

14 Ytterstad B. The Harstad injury prevention study: hospitalbased injury recording used for outcome evaluation of community-based prevention of bicyclist and pedestrian community-based prevention of bicyclist and pede

15 Nordic Medico-Statistical Committee (NOMESCO), $1 \mathrm{st}$ ed. Classification for accident monitoring. Copenhagen NOMESCO, 1984

16 Haddon W. Conference on the prevention of motor vehicle crash injury, 10 January 1979. Israel f Med Sci 1980;16 45-65.

17 American Association for Automobile Medicine (AAA) Abbreviated injury scale (AIS) - 1976 revision. Arlington Heights: AAA, 1976.

18 Dean AG, Dean JA, Burton AH, Dicker RC. Epi Info, version 5: a word processing, database, and statistics program for epidemiology on microcomputers. Stone Mountain Georgia, USA, 1990.

19 Kahn HA, Sempos CT. Statistical methods in epidemiology. Oxford: Oxford University Press, 1989.

20 Schelp L. The role of organizations in community participation - prevention of accidental injuries in a rural participation - prevention of accidental injuries in a rura 